\title{
Improving the Service Quality of Islamic Boarding School based on Importance Performance Analysis Results
}

\author{
Asep Saifuddin Chalima, b*, Mauhibur Rakhmanc, Fadly Usman ${ }^{\mathrm{d}}$ \\ a State Islamic University of Sunan Ampel (UINSA), Surabaya Indonesia \\ b Islamic Religious Institutes of Al-khoziny, Buduran, Sidoarjo, Indonesia \\ c Faculty of Tarbiyah, Institut Pesantren KH Abdul Chalim, Mojokerto, Indonesia \\ d Department of Urban and Regional Planning, Brawijaya University, Indonesia \\ ${ }^{*}$ Corresponding author's email address: asep.chalim@gmail.com
}

\section{A R T I C LE I N F O}

Received: 12-01-2016

Accepted: 21-01-2016

Available online: 10-02-2016

Keywords:

Boarding school,

importance-performance analysis,

Islamic education.

JEL Classification:

A21; C38; I23; M12.

\begin{abstract}
A B S T R A C T
Service quality is very importance aspect in a boarding school. In this research, an importance-performance analysis enables to evaluate the weaknesses of an Islamic boarding school according to service quality factors. This study attempts to understand stakeholders' expectations and perceptions toward boarding school and shows the usefulness of the Importance-performance analysis grid in evaluating the service quality of school This research identifies 35 items and each item is rated using the 5-point of Likert scale. The results are obtained from 350 respondents from students, teachers, and parents. The final results of importance-performance grid show that 12 items fall into quadrant of "Keep up the good work", and 18 items fall into the "Concentrate here" quadrant, 3 items fall into quadrant of "Low priority", and 2 items fall into "Possible overkill" quadrant. The findings of the research show that a school management and facilities aspect are necessary to better organizational characteristics and enhance the service quality of school The results are useful in identifying marketing strategic and help the boarding school develop better service quality.
\end{abstract}

(C) 2016 The Authors. This is an open access article under the terms of the Creative Commons Attribution License 4.0, which allows use, distribution and reproduction in any medium, provided the original work is properly cited.

DOI: http://dx.doi.org/10.18533/rss.v1i2.22

\section{0}

Introduction

The importance and performance analysis method (IPA) is used in market research in order to measure the level of customer satisfaction. The objective of this study is to evaluate and focus the use of IPA as a management tool to measure the quality of boarding school services. We suggest that this method can be easily implemented in other schools, as a performance outcome measure that includes student, teacher and parent input. IPA is an effective and simple technique that can be applied to investigate the customer satisfaction as a function of both to importance and performance (Wu et al, 2010). Importance-performance analysis provides management, which focuses for developing strategies (Matrilla and James, 1977). This research attempts to understand stakeholder (student, teacher and parent) expectations and perceptions of an Islamic boarding school and shows the usefulness of the IPA grid in evaluating school marketing benefits from their perspectives. The results of this research are a survey based random sample of 350 respondents. 
Amanatul Ummah is an Islamic boarding school with good performance and almost all of graduated became a student in famous universities. The authors choose some variables that are considered important in achieving the goal of this study. The results of importance performance analysis show that the internal factor of boarding school is related to the services quality such as school facilities, teacher performance and food management. This paper is organized as follow: section 1, instroduction; section 2, reviews importance-performance analysis; section 3, research instrument, participant characteristic, the methodology applied and data analysis; section 4, findings of the study are described in this section; and finally, conclusion in section 5 .

\subsection{Importance-performance analysis}

IPA is a simple method for simultaneously considering the weaknesses and strengths of a business when evaluate or define a suitable strategy for many purposes (Linda et al, 2010). Matrilla and James (1977) first propose IPA as a useful tool to provide management insights to identify strengths and weaknesses for improving the performance. Educational organizations frequently use IPA as a tool to evaluate strategies and service quality (O’Neill et al, 2004), in service quality of a school, and in a government project (Wong et al., 2011).

Since then, the IPA framework has gained popularity among researchers in service quality (Ennew et al, 1993), and simple tool in evaluating service quality of higher education (Silva et al, 2011). IPA examines not only the performance of an item, but also the importance of that item as a determining factor in satisfaction to the respondent (Silva \& Fernandes, 2010). The combined client ratings for those two components then provide an overall view of satisfaction with clear directives for management and where to focus agency resources (Silva et al, 2011). This method has proven to be a generally applicable tool which is simply to interpret result in extensive use among researchers in various fields. IPA is a way to promote the development of effective strategy, because this method facilitates the interpretation of data and increases usefulness in making strategic decisions (Matzler et al, 2003; Kitcharoen, 2004; Abalo et al., 2007).

The IPA model is a method divided into four quadrants, with the importance on the y-axis and the performance on the x-axis. Quadrant I is labeled "Keep up the Good Work," with high importance and high performance, which indicates that the firm or company has been performing well to gain competitive advantage. Quadrant II is labeled "Concentrate Here," with low performance and high importance, indicating that the firm or company has been performing badly, poorly and requires improvement to be a top priority. Quadrant III is labeled "Low Priority," with low performance and low importance. Any attributes falling into this quadrant are non-important to organizations and or to company. Respondents do not perceive this feature as an important variable. Quadrant IV is labeled "Possible Overkill," with high performance and low importance, indicating that employees or respondents are satisfied with the performance, but the specific attribute is relatively non-important for respondents. In this study, all sub-attributes collected in a single Cartesian diagram. Slightly different from the studies conducted by other researchers (Silva \& Fernandes, 2010; Kitcharoen, 2004; Yu-Chuan Chen et al, 2013) who tend to be more simple and just use the main attributes to analyze the placement of quadrant.

\subsection{Method}

\subsection{Research instrument}

This research measures the variables of service quality in Amanatul Ummah Boarding School by surveying stakeholder perception. A questionnaire is used to collect information and stakeholder perceptions which cover most of the boarding school aspects. It is developed based on an extensive literature review and the author experience.

The instrument comprises two sections; the first section consists of 35 items that measure student activities such as learning activity in the classroom, school facilities, school management, food service and teacher performance. The second section consists of five questions to collect respondent demographics: gender, work years, age, occupation, and education. Likert scale measures the performance and importance attributed to each item in the first section. The "importance" of each attribute is rated using the 5-point Likert scale from 5 (very important) to 1 (very unimportant). The "performance" of each attribute is rated from 5 (very satisfied) to 1 (very unsatisfied). Respondents are asked to asnwer the 35 survey items and rate the degree to which they agree with each item description in the questionnaire, with 1 representing the lowest degree item and 5 representing the highest for all aspects and items.

\subsection{Participant characteristics}

This study focuses on stakeholder attitudes toward development strategy provided by the school service quality. Data are collected at Amanatul Ummah Boarding school, Pacet District, Mojokerto, Indonesia, from October to 
November of 2015. The author distributes 380 questionnaires at this school, and 350 usable questionnaires are returned. The valid return rate is $100 \%$. The percentage of men and women in the sample is $47.71 \%$ and $52.29 \%$. Demographic information such as gender, age, occupation, and education is shown in Table 01.

\begin{tabular}{llrr}
\hline \multicolumn{4}{c}{ Table 01: Demography of respondent } \\
\hline Item & Classification & Number & Percentage \\
\hline Gender & Male & 167 & $47.71 \%$ \\
Age & Female & 183 & $52.29 \%$ \\
& $12-14$ & 82 & $23.43 \%$ \\
& $15-17$ & 93 & $26.57 \%$ \\
Occupation & $17-30$ & 111 & $31.71 \%$ \\
& $>30$ & 64 & $18.29 \%$ \\
& Student & 175 & $50.00 \%$ \\
Education & Teacher & 47 & $13.43 \%$ \\
& Parent & 128 & $36.57 \%$ \\
& Student & 175 & $50.00 \%$ \\
& High School & 53 & $15.14 \%$ \\
& Bachelor & 56 & $16.00 \%$ \\
& Master & 62 & $17.71 \%$ \\
& Doctor & 4 & $1.14 \%$ \\
\hline
\end{tabular}

\subsection{Data analysis}

The author uses IPA to compare the importance and performance of Amanatul Ummah Boarding School in this case study. Although IPA is a traditional tool, it can help to evaluate and analyze organizational service, provide guidance to formulate strategies, and to allocate resources to the right place, the right people and with good facilities. IPA enables management to evaluate and identify the major weaknesses and strengths of organizational success factors. Therefore, this research uses the IPA model to evaluate the performance and importance of boarding school of Amanatul Ummah.

Likert scale measures the performance and importance attributed to each item in the first section. The "importance" of each attribute is rated using the 5-point Likert scale from 5 (very important) to 1 (very un-important). The "performance" of each attribute is rated from 5 (very satisfied) to 1 (very un-satisfied). Respondents are asked to select the 35 survey items and rate the degree to which they agree with each item description and question, with one representing the lowest degree and 5 representing the highest. A total of 350 respondents complete the instrument for this research, and the result is described in Section 4.

\subsection{Results and Analysis}

This research differentiates the investigated into two groups of aspects and eight categories. The first group is management aspects comprising (a) Educational system, such as method, learning environment, learning material, daily exercise and homework (5 items); (b) school expense; entry tuition fee, other dues (3 items); (c) school facilities, such as security system and food system (2 items); and, (d) teacher, such as intelligent, professionalism, skill, competence, attitude (5 items). Second group is facility aspects; (e) mosque, such as cleanliness, neatness, speaker system, and lighting (4 items), (f) cafeteria (canteen), such as cleanliness, neatness, food, drink and goods (5 items), (g) hostel, such as cleanliness, neatness, quantity, natural air and bed (5 items), and (h) toilet, such as cleanliness, neatness, quantity, water and lighting (5 items).

Based on the eight categories, the thirty-five question and 5-point Likert-type questions are selected. A full list of the 35 refined scale items is shown in Table 2 which examines the response across the scale items to assess employee perceptions of boarding school services and the importance assigned by all respondents to each item. Table 2 shows the average and value difference between importance and performance for 35 items which are grouped around the previously identified factor structure. All importance scores are shown to significantly differ from performance scores. A further examination shows that the importance means for all items are higher than the means of performance. This reflects the existence of a quality gap. Whereas respondents consider each of 
these items become a significant importance in their overall evaluation of their experience, the school facility is not performing at a level that reflects the assigned importance. Analyzing the findings in terms of quadrants as in Figure 1, 35 items fell under quadrants 1 to quadrant 4. In Figure 1, the x-axis represents their performance perception, while the y-axis represents their importance perception. The cross-hairs (vertical and horizontal of red lines) are located at the grand-mean scores. The mean values for overall importance (4.50) and performance (3.50) are used to split the axes which similar to the suggestion by Matrilla and James (1977) that cross-hair placement is a relative judgment rather than an absolute measure.

\begin{tabular}{|c|c|c|c|c|c|c|c|c|}
\hline \multicolumn{9}{|c|}{ Table 02: Importance and performance results } \\
\hline \multirow[t]{3}{*}{ No } & \multirow[t]{2}{*}{ Code } & \multirow[t]{2}{*}{ Atribut } & \multicolumn{2}{|c|}{ Importance } & \multicolumn{2}{|c|}{ Performance } & \multirow{3}{*}{$\bar{Y}=\frac{\sum \bar{Y}}{K}$} & \multirow[b]{2}{*}{$\bar{X}=\frac{\sum \bar{X}}{K}$} \\
\hline & & & Average & Value $(\Sigma y)$ & Average & Value $(\Sigma x)$ & & \\
\hline & A & Education system & & & & & & \\
\hline 1 & A. 1 & Methode & 298.8 & $1,494.0$ & 316.2 & $1,581.0$ & 4.27 & 4.52 \\
\hline 2 & A. 2 & Learning Environment & 304.0 & $1,520.0$ & 327.8 & $1,639.0$ & 4.34 & 4.68 \\
\hline 3 & A. 3 & Learning Material & 324.0 & $1,620.0$ & 322.4 & $1,612.0$ & 4.63 & 4.61 \\
\hline 4 & A. 4 & Daily Exercise & 323.2 & $1,616.0$ & 338.2 & $1,691.0$ & 4.62 & 4.83 \\
\hline \multirow[t]{2}{*}{5} & A. 5 & Home Work & 317.4 & $1,587.0$ & 309.2 & $1,546.0$ & 4.53 & 4.42 \\
\hline & B & School Expense & & & & & & \\
\hline 6 & B. 1 & Entry Tution Fee & 287.2 & $1,436.0$ & 237.0 & $1,185.0$ & 4.10 & 3.39 \\
\hline 7 & B. 2 & Monthly dues & 285.6 & $1,428.0$ & 192.4 & 962.0 & 4.08 & 2.75 \\
\hline \multirow[t]{2}{*}{8} & B. 3 & Other dues & 229.6 & $1,148.0$ & 161.0 & 805.0 & 3.28 & 2.30 \\
\hline & $\mathrm{C}$ & School Facilites & & & & & & \\
\hline 9 & C. 1 & Security system & 329.0 & $1,645.0$ & 194.4 & 972.0 & 4.70 & 2.78 \\
\hline \multirow[t]{2}{*}{10} & C. 2 & Food system & 327.6 & $1,638.0$ & 168.0 & 840.0 & 4.68 & 2.40 \\
\hline & $\mathrm{D}$ & Teacher & & & & & & \\
\hline 11 & D. 1 & Intelligent & 332.0 & $1,660.0$ & 242.0 & $1,210.0$ & 4.74 & 3.46 \\
\hline 12 & D.2 & Profesionalism & 335.6 & $1,678.0$ & 256.4 & $1,282.0$ & 4.79 & 3.66 \\
\hline 13 & D. 3 & Skill & 337.0 & $1,685.0$ & 268.2 & $1,341.0$ & 4.81 & 3.83 \\
\hline 14 & D. 4 & Competence & 333.0 & $1,665.0$ & 255.6 & $1,278.0$ & 4.76 & 3.65 \\
\hline \multirow[t]{2}{*}{15} & D.5 & Attitude & 340.8 & $1,704.0$ & 297.0 & $1,485.0$ & 4.87 & 4.24 \\
\hline & $\mathrm{E}$ & Mosque & & & & & & \\
\hline 16 & E.1 & Cleanliness & 344.4 & $1,722.0$ & 188.4 & 942.0 & 4.92 & 2.69 \\
\hline 17 & E. 2 & Neatness & 342.8 & $1,714.0$ & 179.8 & 899.0 & 4.90 & 2.57 \\
\hline 18 & E. 3 & Speaker system & 331.4 & $1,657.0$ & 306.2 & $1,531.0$ & 4.73 & 4.37 \\
\hline \multirow[t]{2}{*}{19} & E.4 & Lighting & 329.4 & $1,647.0$ & 309.8 & $1,549.0$ & 4.71 & 4.43 \\
\hline & F & Cafetaria & & & & & & \\
\hline 20 & F.1 & Cleanliness & 324.6 & $1,623.0$ & 187.4 & 937.0 & 4.64 & 2.68 \\
\hline 21 & F.2 & Neatness & 334.0 & $1,670.0$ & 184.4 & 922.0 & 4.77 & 2.63 \\
\hline 22 & F.3 & Food & 324.0 & $1,620.0$ & 223.2 & $1,116.0$ & 4.63 & 3.19 \\
\hline 23 & F.4 & Drink & 328.0 & $1,640.0$ & 184.0 & 920.0 & 4.69 & 2.63 \\
\hline 24 & F.5 & Goods & 327.0 & $1,635.0$ & 264.8 & $1,324.0$ & 4.67 & 3.78 \\
\hline \multirow[t]{2}{*}{25} & F.6 & Price & 301.6 & $1,508.0$ & 154.0 & 770.0 & 4.31 & 2.20 \\
\hline & G & Hostel & & & & & & \\
\hline 26 & G.1 & Cleanliness & 345.6 & $1,728.0$ & 170.0 & 850.0 & 4.94 & 2.43 \\
\hline 27 & G.2 & Neatness & 331.8 & $1,659.0$ & 162.0 & 810.0 & 4.74 & 2.31 \\
\hline
\end{tabular}




\begin{tabular}{rrlrrrrrr}
\hline 28 & G.3 & Quantity & 345.6 & $1,728.0$ & 153.4 & 767.0 & 4.94 & 2.19 \\
29 & G.4 & Natural air & 327.8 & $1,639.0$ & 275.6 & $1,378.0$ & 4.68 & 3.94 \\
30 & G.5 & Bed & 326.8 & $1,634.0$ & 173.4 & 867.0 & 4.67 & 2.48 \\
& H & Toilet & & & & & & \\
31 & H.1 & Cleanliness & 331.6 & $1,658.0$ & 177.4 & 887.0 & 4.74 & 2.53 \\
32 & H.2 & Neatness & 341.4 & $1,707.0$ & 178.8 & 894.0 & 4.88 & 2.55 \\
33 & H.3 & Quantity & 346.0 & $1,730.0$ & 181.0 & 905.0 & 4.94 & 2.59 \\
34 & H.4 & Lighting & 327.0 & $1,635.0$ & 289.0 & $1,445.0$ & 4.67 & 4.13 \\
35 & H.5 & Water & 338.6 & $1,693.0$ & 193.2 & 966.0 & 4.84 & 2.76 \\
\hline
\end{tabular}

The following paragraphs describe each IPA quadrant in detail.

1) The "Keep up the good work" quadrant. All items that fall into this quadrant are the management and service strength of the boarding school. Respondents believe this specific attribute to be crucial and are satisfied with performance. This quadrant, comprising twelve items, suggests areas where the boarding school of Amanatul Ummah is doing well and must continue the good work.

2) The "Concentrate here" quadrant. Items that fall into this quadrant represent key areas that must improve as a top priority. Eighteen items are located in this zone. Include 3 items of managerial aspects (security system, and food system intelligent of teacher) belong to the school facility variables which demand immediate action from the school.

3) The "Low priority" quadrant. Any item that falls into this quadrant is non-important and does not pose a school threat. Consequently, it is unnecessary for management to focus additional effort here. Three items (tuition fees, monthly dues and price of the goods in the cafeteria) are located in this zone.

4) The "Possible overkill" quadrant is overly emphasized by the school, which should allocate more resources to manage items that reside in the "Concentrate here" quadrant. This quadrant reflects a lower and misuse of school resources. Two items (method and learning environment) belong to this quadrant. The management aspects located in this zone are a low-priority region.

Figure 1: The quadrant of Importance-Performance Analysis

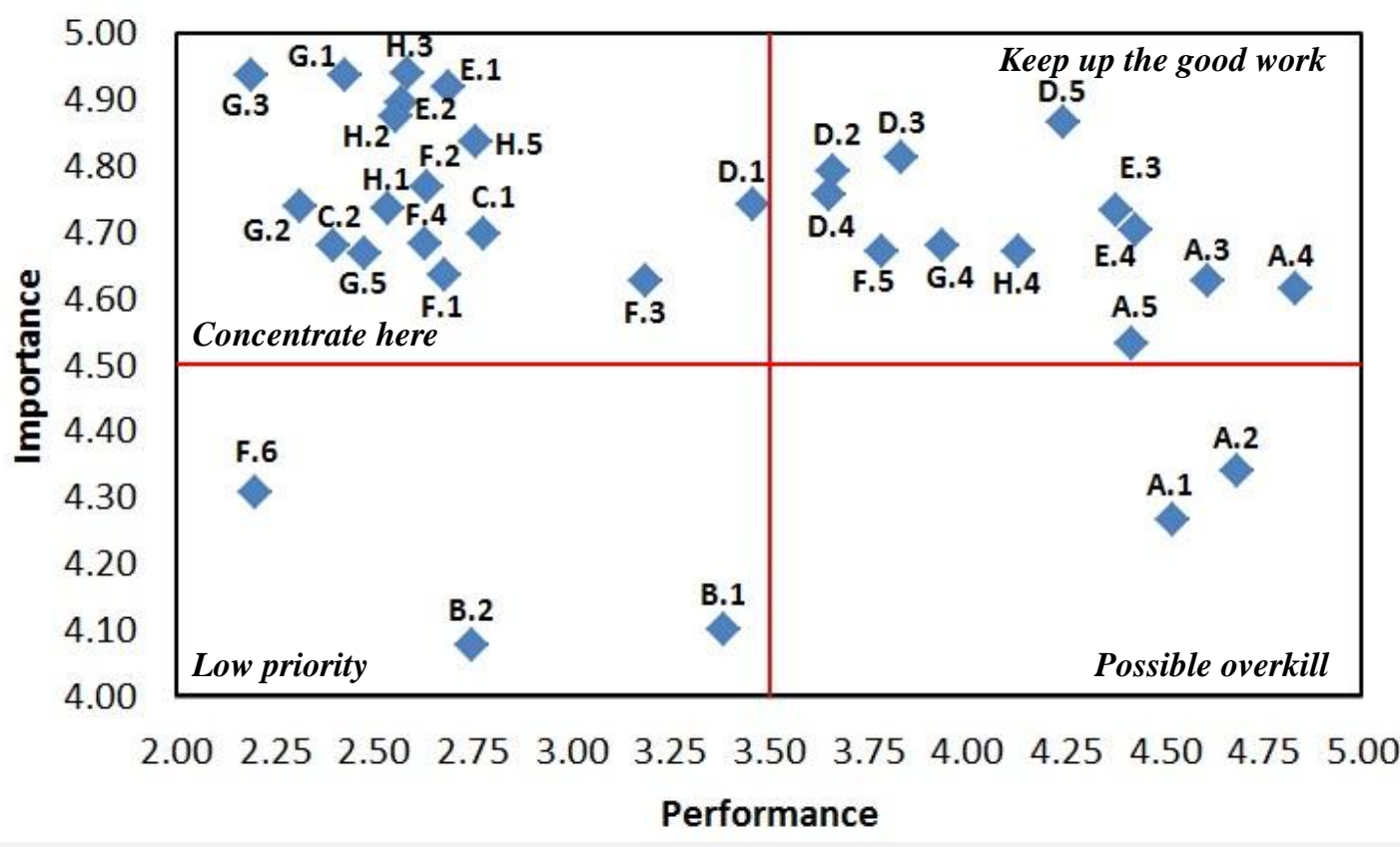

\subsection{Conclusion}

The results of importance-performance grid show that 12 items fall into the "Keep up the good work" quadrant, 18 items fall into the "Concentrate here" quadrant. Three items fall into the "Low priority" quadrant, and two items fall into the "Possible overkill" quadrant. These findings suggest that management and facility aspects are necessary to better match with the organizational characteristics and enhance the service quality. IPA results 
indicate that management aspects in Amanatul Ummah boarding school are running well, which fall into "Keep up the good work" quadrant. On the other side, the quadrant of "Concentrate here" should direct attention from school management and requires more resources to making improvement in this quadrant. Eighteen items fall into this quadrant dominated by physical aspects such as cafeteria, mosque, hostel and toilet.

This research results provide further evidence of the importance of the education system, and management can use these IPA results to create a development strategy and upgrading the building quality aspect based on the performance and importance shown in the four quadrants from respondent's perspective. IPA in this research is an effective method to measure student's perspective on good facility, teacher performance, building facilities, and the others. The finding suggests that management of school is necessary to improve and should be in better condition than now, such as facilities of toilet, hostel, cafeteria, cleanlianess of the mosque, and others.

There are some steps which are not clear completely such as the limitations of 35 items of research variables. The authors could add more variables and analyse it altogether in the table of IPA. On the other side, some results between performance and importance have shown GAP of values. This is because the importance and performance ratings might be influenced by respondent demographic experiences and backgrounds. Future studies can explore management and building facility aspect across various organizations. This study does not allow for applying methods such as the AHP, GAP analysis, and other multi-attribute utility frameworks. Perhaps interested researchers could conduct similar studies from these perspectives.

\section{Acknowledgments}

This work has been supported by Department of Tarbiyah, Institute Pesantren KH Abdul Chalim, Mojokerto, Indonesia. The authors would like to thank the students, teachers and parents who answered the questionnaires and other teachers for allowing time in their classes for carrying out the survey. We would also like to thank Amanatul Ummah Boarding School's principal for authorizing the use of the questionnaires in this research.

\section{References}

Abalo, J., Varela, J. and Manzano, V. (2007), Importance values for Importance-Performance Analysis: A formula for spreading out values derived from preference rankings, Journal of Business Research, 60(2), 115-121.

Ennew, C.T., Reed, G.V. and Binks, M.R. (1993), Importance-performance analysis and the measurement of service quality. European Journal of Marketing, 27, 59-70. http://dx.doi.org/10.1108/03090569310026402.

Kitcharoen, K. (2004), The importance-performance analysis of service quality in administrative departments of private universities in Thailand, ABAC Journal, 24(3), 20-46.

Linda, S. L., \& To, W. M. (2010). Importance-Performance Analysis for Public Management Decision Making: An empirical study of China's special administrative region. Management Decision, 48 (2), pp. 277-295. http://dx.doi.org/10.1108/00251741011022626.

Martilla, J. and James, J. (1977) Importance-Performance Analysis. Journal of Marketing, 41, 77-79. http://dx.doi.org/10.2307/1250495.

Matzler, K., Sauerwein, E. and Heischmidt, K. (2003), Importance-performance analysis revisited: The role of the factor structure of customer satisfaction, The Service Industries Journal, 23(2), 112-129.

O’Neill, M. A., \& Palmer, A. (2004). Importance-performance analysis: A useful tool for directing continuous quality improvement in higher education. Quality Assurance in Education, 12(1), 39-52. http://dx.doi.org/10.1108/09684880410517423.

Silva, F. and Fernandes, O. (2010). Using Importance-Performance Analysis in Evaluating of Higher Education: A Case Study. ICEMT 2010 International Conference on Education and Management Technology. IEEE. ISBN: 978-1-4244-8617-5, 121-123.

Silva, F. and Fernandes, O. (2011) Importance-Performance Analysis As A Tool In Evaluating Higher Education Service Quality: The Empirical Results Of Estig (IPB), Creating Global Competitive Economies: A 360-Degree Approach, 306-315.

Wong, M. S., Hideki, N., \& George, P. (2011). The use of Importance-Performance Analysis (IPA) in Evaluating Japan's e-government Services. Journal of Theoretical and Applied Electronic Commerce Research, 6(2), 17-30.

Wu, H. H., \& Shieh, J. I. (2010). Quantifying Uncertainty in Applying Importance-Performance Analysis. Qualityand Quantity, 44, 997-1003. http://dx.doi.org/10.1007/s11135-009-9245-8.

Yu-Chuan Chen \& Shinyi Lin (2013). Applying Importance-Performance Analysis for Improving Internal Marketing of Hospital Management in Taiwan International, Business Research; Vol. 6, No. 4, pp. 46-54. 